are applicable to motorists, whose movements are dependent on rapid and accurate co-ordination between the eyes, hands and feet. The committee also emphasises that the elimination of alcohol from the body is a slow process : 10-12 c.c., or the equivalent of one ounce of whisky, can be oxidised each hour, and the rate is not increased when the concentration in the blood is raised by drinking larger quantities. The committee concludes that the driving capacity of a driver, who has taken even small amounts of alcohol, must frequently be adversely affected, even when it has been consumed some hours before driving, and especially if taken in the absence of food.

\section{Production of Oil in Great Britain}

ONE of the most striking characteristics of the times is the tendency of man to make himself less dependent on the circumstances imposed by geographical conditions. Formerly it was necessary to settle, and for industries to develop, where sources of food and raw materials were readily accessible. Now the tendency is for these things to be done just where man chooses--but at a certain price. Modern civilisation demands oil and oil products, and our need is being in part met by the treatment of coal. In the House of Commons on July 24, the Secretary for Mines (Captain Crookshank) reported that the plant at Billingham for coal-hydrogenation is now working and will, when at full output, produce $45,000,000$ gallons of motor spirit yearly- $3 \frac{3}{4}$ per cent of our annual consumption. By August, the total production -including that from distillation of oil shale and coal-will reach $60,000,000$ gallons, increasing to $90,000,000$ gallons when the Billingham plant attains full output. Although petroleum can be got from the earth for relatively slight efforts, one of the chief merits claimed for coal-hydrogenation is the magnitude of the labour it requires and the employment it gives. This, however, is small in comparison with the size of the coal industry. The present Billingham output employs 1,900 miners and 1,000 plant employees, and it does not seem probable that the process can restore the former prosperity of the mining industry. Capt. Crookshank also stated that 43 applications had been received to prospect and work for oil in Great Britain.

\section{Mr. Lloyd George's Scheme of National Reconstruction}

Mr. Lloyd George's scheme of national reconstruction is outlined in a pamphlet entitled "Organizing Prosperity" (Ivor Nicholson and Watson. 6d.). His main thesis is that our oconomic system can be amended without being scrapped, and that the immense advantages of individual enterprise, energy and initiative which our present economic system fosters are not to be lightly sacrificed. They must rather be controlled and cultivated so that they may yield an ordered harvest for the nation. He gives first place to the land as a means of finding not only temporary employment during a period of exceptional trade depression, but also permanent employment for our surplus population. Other projects advocated include housing and slum clearance, electrification of suburban railways, improvement of ports and docks, extension and improvement of electrical supply, road developments, water supply, telephone extensions and financial assistance for development of oversea markets. These various schemes would be financed by a 'prosperity loan', while the carrying out of the programme would be entrusted to a National Development Board consisting of a small body of persons of distinguished competence drawn from industry, commerce, finance, workers and consumers who would be appointed for a definite term and would be responsible to the Cabinet. But since a Cabinet of about a score of Departmental Ministers is an unsuitable body to give full and dispassionate consideration to bold schemes of national reconstruction, Mr. Lloyd George advocates a reversion to the War-time arrangement of an executive consisting of the Prime Minister and four or five Ministers without departmental duties.

\section{Science and Vocational Advice}

IN a Friday evening discourse delivered at the Royal Institution on May 10, and now available as a pamphlet, Dr. C. S. Myers discussed the "Scientific Approach to Vocational Guidance". He compared the giving of vocational advice with the giving of medical advice. Each is an art, yet each depends on the use of scientific knowledge and methods. The individual must be studied with regard to every relevant aspect of himself and his environment. In vocational guidance, the part played by psychological tests is essential, although relatively small. It is now possible to estimate intelligence fairly accurately, by means of 'verbal' and 'practical' tests, and as the degree of intelligence required varies in different groups of occupations, this is one very important deciding factor. But tests for character and temperamental qualities are not yet sufficiently reliable; and the chief contribution of the psychologist in this direction has been in the introduction of improved and systematic methods of assessment. Other qualities necessary for success in certain occupations are mechanical ability and manual ability. Tests for these abilities and others, based on a detailed study of some one occupation, can be applied in vocational selection where the problem is one of selecting the best person for a particular job. The co-operation of parents, teachers, school authorities and juvenile employment officers provides a necessary contribution to the data on which the vocational adviser's advice is based. The follow up of advised cases, and comparison with the results obtained from a control-group are now recognised parts of the experimental procedure. During the past nine years, the number of cases dealt with in Great Britain by the two bodies responsible for most of such research was 6,751; in 1925 the number of vocational guidance cases was less than 100 .

\section{T. A. Coward Memorial Sanctuaries}

ON July 22, the Earl of Crawford and Balcarres opened the Nature sanctuary at Cotterill Clough. 